\title{
Moscow's Cold War on the Periphery: Soviet Policy in Greece, Iran, and Turkey, I 943-8
}

\begin{abstract}
This article examines Soviet policy towards Greece, Iran and Turkey during the early Cold War. It argues that Stalin's aims in relation to these countries were limited and secondary to more important goals in Europe. Equally, the postwar crises in Greece, Turkey, and Iran played a critical role in shaping differing Soviet and Western perceptions of the causes of the Cold War. An important part of the story on the Soviet side was the role of wounded national pride in propelling Stalin into the Cold War.
\end{abstract}

Keywords: Cold War, Greece, Iran, Soviet foreign policy, Stalin, Turkey

The prevailing idea that the origins of the Cold War were largely a function of the Soviet-American confrontation in central Europe has had many critics. Some historians have highlighted the role of the European powers themselves in precipitating the Cold War, ${ }^{1}$ while others have stressed the Far Eastern dimension of Soviet-American postwar rivalry, particularly the impact of 'atomic diplomacy'. 2 Still others have focused on the impact of events on the USSR's southern flank: the civil war in Greece; the crisis over Soviet troop withdrawals from Iran in 1946; and Soviet-Turkish tensions over the control of the Black Sea Straits. According to Bruce R. Kuniholm's classic study of Soviet-Western clashes over Iran, Turkey and Greece, 'the historical struggle for power along the Northern Tier [was] an important factor in the origins and development of what later became known as the Cold War'. Soviet aims in relation to Greece, Iran and Turkey, argued Kuniholm, were 'to secure their southern flank, to rid that region of Anglo-American influence and at the same

I would like to acknowledge the comments on earlier drafts of this article of Carlone Kennedy-Pipe, Mel Leffler, Jeremi Suri and the late Eduard Mark.

1 For example, A. Deighton, The Impossible Peace: Britain, the Division of Germany and the Origins of the Cold War (Oxford 1990).

2 A recent example is: C. Craig and S.G. Radchenko, The Atomic Bomb and the Origins of the Cold War (London and New Haven, CT, 2008). 
time acquire a springboard to the Eastern Mediterranean and the Middle East." In another wide-ranging challenge to the conventional, Eurocentric narrative, John Kent argued that it was not so much the struggle with the Western powers in Germany and Eastern Europe that drove Stalin to the Cold War as the simultaneous exclusion of the USSR from British and American spheres of influence in the Near, Middle and Far East. From Stalin's point of view, the Western powers were seeking to deny him the right to an exclusive sphere of influence in Eastern Europe whilst at the same time frustrating Soviet ambitions to play an important role in other parts of the world. ${ }^{4}$ More recently, the Azeri historian Jamil Hasanli has reasserted the argument that the Cold War began with the crises in Iran and Turkey, contending that it was in these countries that the Soviets suffered their first defeats in the postwar conflict with the West. ${ }^{5}$

The problem with the view of Kuniholm, Kent and Hasanli is that, while Stalin posed and postured on the southern periphery of his postwar empire, he did not press his demands too hard: he did little or nothing to stop the crushing of the communist-led insurgency in Greece; withdrew his troops from Iran only two months after the agreed deadline; and rapidly backed away from confrontation with Turkey over the Straits. The pattern that emerges from a detailed study of Soviet policy along the southern periphery, based on the latest findings from the Russian archives, is that, while Stalin sought economic, political and strategic gains in Greece, Iran, and Turkey, he was unwilling to jeopardize more important aims in the central European theatre. Stalin's main priority was the maintenance of the Soviet sphere of influence in Eastern Europe, preferably in the context of a peacetime Grand Alliance with Britain and the United States. That meant a policy of relative restraint in relation to peripheral areas and issues of dispute, such as those in relation to Greece, Iran and Turkey. That does not mean the crises in Greece, Iran and Turkey played no role in the origins of the Cold War. As many historians have shown, the interpretation of these events was crucial in shaping hostile Western perceptions of Stalin's postwar policy. Moscow may have seen Soviet demands as reasonable, but that was not how they were viewed in London and Washington. On the Soviet side

3 B.R. Kuniholm, The Origins of the Cold War in the Near East: Great Power Conflict and Diplomacy in Iran, Turkey, and Greece (Princeton, NJ, 1980), xv-xvi, 379.

4 J. Kent, 'The British Empire and the Origins of the Cold War, 1944-1949', in A. Deighton (ed.), Britain and the First Cold War (New York 1990).

5 J. Hasanli, At the Dawn of the Cold War: The Soviet-American Crisis over Iranian Azerbaijan, 1941-1946 (Lanham, MD, 2006) [in Russian: SSSR-Iran: Azerbaidzhanskii Krizis i Nacholo Kholodnoi Voiny, 1941-1946 (Moscow 2006)]; Dzh. Gasanly [J. Hasanli], SSSR-Turtsiya: Poligoi Kholodnoi Voiny (Baku 2005); J. Gasanly [J. Hasanli], 'Iranian Azerbaijan: The Epicenter of the Cold War', The Caucasus and Globalization 2(1-2) (2008); and idem, 'The "Turkish Crisis" of the Cold War Period and the South Caucasian Republic", The Caucasus and Globalization 2(2) (2008) and 3(1) (2009). Hasanli's publications contain a wealth of detailed material from the Russian, Georgian, and Azerbaijani archives. I am grateful to him for providing me with copies of his two articles. 
of the equation, the frustration of Stalin's goals in Greece, Iran, and Turkey were seen as part of a pattern of Western efforts to deny the USSR the fruits of its victory in the Second World War. This perception was sharpened by the Soviet regime's sense of patriotic self-esteem and the feeling that the Western powers did not appreciate the huge sacrifices made by the USSR to defeat nazi Germany.

As early as summer 1943, Soviet policy-makers began to locate Greece in a British sphere of interest in the Eastern Mediterranean. Internal briefing papers prepared for the Moscow Conference of Foreign Ministers of October 1943 noted the importance of British interests in Greece, while Soviet interests were deemed to lie in an extension of Moscow's influence in the Slavic states of the Balkans. ${ }^{6}$ These themes were taken up by Ivan Maiskii - the former Soviet ambassador in London - in a memorandum to Vyacheslav Molotov, the Soviet foreign commissar, in January 1944. The memo was a speculative survey of the USSR's postwar prospects and perspectives, rather than a statement of policy or strategy, but its view of Greece can be taken as typical of the thinking and discourse within the foreign commissariat:

The USSR is interested in Greece much less than in other Balkan countries, whereas England, in contrast, is seriously interested in Greece. In relation to Greece, therefore, the USSR should observe great caution. If democratic Greece, following the example of other Balkan countries, would also like to conclude a pact of mutual assistance with the USSR, we would have no reason to discourage it. However, if the conclusion of a bilateral Greek-Soviet pact caused some complications with England, one could try to deal with the problem by way of the conclusion of a trilateral mutual assistance pact between England, Greece and the USSR (as in the case of Iran). ${ }^{7}$

It seems that Stalin and Molotov took such considerations to heart. When a Soviet military mission was dispatched to the communist-led partisan army ELAS in summer 1944, its officers went with instructions not to involve themselves in Greek internal affairs. ${ }^{8}$ In October 1944, Stalin told Churchill that 'he agreed that England must have the right of the decisive voice in Greece. ${ }^{9}$ This statement was made during the notorious 'percentages' discussion of 9 October 1944. Stalin made this concession even before Churchill produced his eponymous piece of paper detailing an Anglo-Soviet percentage division of influence in Bulgaria, Hungary, Romania, Yugoslavia and Greece (90-10 per cent in Britain's favour, in the latter instance). Averell Harriman, the American ambassador in Moscow, was not present at the meeting, but he picked up on the significance of the discussion concerning Greece in a telegram to Roosevelt

6 Arkhiv Vneshnei Politiki Rossiiskoi Federatsii (hereafter 'AVPRF') F.6, Op.5b, Pap.39, D1.

7 G.P. Kynin and J. Laufer (eds), SSSR $i$ Germanskii Vopros, vol.1 (Moscow 1996), document 79.

8 P.J. Stavrakis, Moscow and Greek Communism, 1944-1949 (Ithaca, NY, 1989), 28-9.

9 Rossiiskii Gosudarstvennyi Arkhiv Sotsial'no-Politicheskoi Istorii (hereafter 'RGASPI') F.558, Op.11, D.283, L.6. 
on 11 October:

As to Greece, the Prime Minister feels that he has already obtained Stalin's approval to keep hands off and to use Soviet influence to prevent the Greek Communists from being a disruptive influence and to induce them to play a constructive part in a national government. ${ }^{10}$

Another sign of the prevailing Soviet assumption that Greece was in the British sphere of influence was a report in November 1944 by Maksim Litvinov 'On the Prospects and Basis of Soviet-British Cooperation'. Litvinov, Molotov's predecessor as foreign commissar, was the head of the Foreign Commissariat's postwar planning commission and he wrote a number of reports during the war speculating on the shape of the postwar world. ${ }^{11}$ This particular report envisaged an Anglo-Soviet division of postwar Europe into spheres of security and, according to Litvinov's schema, Greece was allocated to the British sphere along with Holland, Belgium, France, Spain, and Portugal. ${ }^{12}$

Stalin was as good as his word to Churchill in October 1944. When an armed communist revolt against British control broke out in Athens in December 1944, Georgi Dimitrov, the former Comintern leader, asked Molotov if the Greek comrades could expect assistance in order to oppose armed intervention by England'. The reply was that 'our Greek friends will not be able to count on active assistance from here [Moscow]'. ${ }^{13}$ In January 1945 Stalin told a Yugoslav delegation that 'the British were surprised when they saw the Red Army was not moving into Greece. They cannot understand a strategy that forbids the army to move along divergent lines. The strategy of the Red Army is based on movement along convergent lines. ${ }^{14}$ The next day Stalin pronounced on Greek developments to Dimitrov:

I advised not starting this fighting in Greece. The ELAS people should not have resigned from the Papandreou government. They've taken on more than they can handle. They were evidently counting on the Red Army's coming down to the Aegean. We cannot do that. We cannot send our troops into Greece, either. The Greeks have acted foolishly. ${ }^{15}$

Pessimism about the prospects for armed resistance was the consistent theme of Soviet responses to the developing crisis in Greece. While communist press coverage of the ELAS position in Greece was sympathetic and supportive,

10 Foreign Relations of the United States 1944, vol. 4, 1010.

11 See G. Roberts, 'Litvinov's Lost Peace, 1941-1946', Journal of Cold War Studies 4(2) (Spring 2002).

12 Litvinov's report is cited in detail in V.O. Pechatnov, The Big Three after World War II: New Documents on Soviet Thinking about Postwar Relations with the United States and Great Britain, Cold War International History Project Working Paper no.13 (1995).

13 The Diary of Georgi Dimitrov 1933-1949 (New Haven, CT, 2003), 345 (diary entries for 8 and 9 December 1944).

14 Vostochnaya Evropa v Dokumentakh Rossiiskikh Arkhivov, 1944-1953, vol. 1 (Moscow 1997), document 37.

15 The Diary of Georgi Dimitrov, op. cit., entry for 10 January 1945, 352-3. 
confidential estimates of its prospects for success were more restrained. The Soviet Communist Party's central committee confidential bulletin on foreign affairs carried a number of articles on events in Greece, but none conveyed any confidence that ELAS could win the civil war. ${ }^{16}$ For its part, the Soviet leadership was persistent in its efforts to restrain the radicalism of the Greek Communist Party (KKE). In January 1946 Molotov urged the Greek communists 'not to yield to provocations or ignite domestic armed conflicts that would provide a justification for the continued presence of British troops in Greece'. ${ }^{17}$ On 9 February Dimitrov recorded in his diary:

Received an answer from... [Molotov] to a question posed by the Greek comrades - Shall they prepare for an armed uprising against the react[ionary] monarchist regime, or shall they organize their self-defense, combined with the political mobilization of the pop[ular] masses? The second is recommended. ${ }^{18}$

On 2 September 1946, Dimitrov noted in his diary that 'on the tactics of the Gree[k] Com[munist] Party, St[alin] stressed the fact that the Greek Communists earlier made an error with the boycott of the parliamentary elections: "boycotting makes sense when it brings about the failure of elections. Otherwise, a boycott is a foolish thing.", 19

On 22 May 1947, KKE leader Niko Zachariadis met with Soviet ideology chiefs Andrei Zhdanov and Mikhail Suslov in Moscow. Zachariadis painted a glowing picture of the partisan movement and its prospects, emphasizing that we have a 'realistic perspective of cleansing Greece'. Zachariadis wanted to know why the USSR couldn't become more active in Greek affairs, stating that the Soviet Union was greatly loved and respected by the Greek people and that 'many regretted that the Soviet army did not come to Greece'. Zhdanov, who was receiving the KKE leader on Stalin's behalf, remained non-committal throughout the conversation and restricted himself to a couple of questions about the strength of enemy forces and the possibility of forming a regular as well as a partisan army. ${ }^{20}$

In the diplomatic sphere, Soviet policy in relation to Greece followed a similar pattern of restraint. In January 1945, on the eve of the Yalta conference, Andrei Gromyko, the Soviet ambassador in Washington, wrote a briefing paper that considered recent events in Athens and noted British and American opposition to the progressive forces in Greece. He recommended that the Soviet side should not take any initiative in relation to Greece, except to make clear that it sympathized with the progressive elements. ${ }^{21}$

16 For example, 'K sobytiyam v Gretsii', Voprosy Vneshnei Politiki, no.2, January 1945, RGASPI, F17, Op.128 d.12.

17 Molotov's words as paraphrased by T.D. Sfikas, 'War and Peace in the Strategy of the Communist Party of Greece, 1945-1949', Journal of Cold War Studies 3(3) (2001), 9-10.

18 Dimitrov Diary, op. cit., 396.

19 Ibid., 414.

20 RGASPI F.77, Op.3, D.143, LL.1-12.

21 AVPRF F.06, Op.7a, D.5, LL.11-12. 
In line with this approach, when Stalin broached the question of Greece at Yalta he made it clear that he was seeking information, not attempting to interfere with British policy in the country. When Molotov raised with Eden, the British Foreign Secretary, the inclusion in the Declaration on Liberated Europe of a reference to the principle of non-interference in countries' internal affairs, he hastened to 'repeat the words of comrade Stalin that he did not have in mind the position in Greece.'22

By the time of the Potsdam Conference, however, the Soviet position on Greece was beginning to change. On 20 July 1945 the Soviet delegation submitted a memorandum on the implementation of the Declaration on Liberated Europe which criticized the reign of terror in Greece against the 'democratic elements' and called for the immediate formation of a democratic government in Greece. ${ }^{23}$ This memorandum presaged the main theme of Soviet diplomacy on the Greek question for the next few months: criticism of Western policy in Greece coupled with efforts to trade Moscow's relative reticence on Greek issues in exchange for Western recognition of the pro-Soviet Bulgarian and Romanian governments.

At the next Allied conference - the first session of the Council of Foreign Ministers (CFM) in London in September 1945 - the Soviets tabled a relatively mild statement expressing concern at developments in Greece, declaring that they could not 'accept any moral responsibility whatsoever for the political situation' in the country. ${ }^{24}$

The main business of the CFM was the negotiation of peace treaties for the minor Axis states: Bulgaria, Finland, Hungary, Italy, and Romania. However, Britain and the United States refused to sign peace treaties with Bulgaria and Romania until their governments were reorganized and general elections held. In private conversations with James F. Byrnes, the US Secretary of State, Molotov countered queries concerning Bulgaria and Romania by pointedly referring to the Greek government, which, he said, did not have the support of the people. 'Why does the American government', asked Molotov, 'only want to reform the government in Romania before elections and not in Greece? It seems that the United States does not want to interfere with the English in Greece, but it does with the Russians in Romania. ${ }^{25}$ Molotov had similar exchanges with Bevin, the British foreign minister, but he, like Byrnes, refused to accept the Greek analogy and continued to withhold recognition of

22 AVPRF F.06, Op.7a, D.8, L.39. This exchange is omitted from all published Soviet records, an omission designed to cover up Soviet appeasement of Britain in relation to the Greek question. For further examples of omissions in relation to Greece and other topics, see G. Roberts, 'Stalin at the Tehran, Yalta and Potsdam Conferences', Journal of Cold War Studies (December 2007).

23 Berlinskaya (Potsdamskaya) Konferentsiya Rukovoditelei Trekh Souznykh Derzhav - SSSR, SShA, $i$ Velikobritanii (Moscow 1984), document 47.

24 Sessiya Soveta Ministrov Inostrannykh Del v Londone 11 Sentyabrya - 2 Oktyabrya 1945 goda: Stenograficheskiye Zapisi Zasedanii, AVPRF, F.0431/1, Op.1, D.5, L.16.

25 Molotov meeting with Byrnes, 19 September 1945. AVPRF F.0431/1, Op.11, Pap.4, D.18, L.24. See also Sovetsko-Amerikanskiye Otnosheniya, 1945-1948 (Moscow 2004), document 9. 
the Bulgarian and Romanian governments. It was because of this dispute that the CFM session ended on 2 October 1945 without agreement.

The wrangling about Greece, Bulgaria and Romania continued at a special tripartite conference of Britain, the USA and the USSR held in Moscow in December 1945. At this conference Soviet policy in relation to Greece took a new turn, with a demand for the withdrawal of British forces. This was partly a tactical stance designed to counter Western demands for Soviet troop withdrawals from other countries, including Iran. But the demand also augured a substantial Soviet campaign in 1946 for a general withdrawal of Western armed forces from foreign countries. ${ }^{26}$ This campaign was linked to a growing perception in Moscow that Britain and the United States intended to maintain a global chain of military bases in the postwar world, whilst at the same time insisting on Soviet troop withdrawals. In May 1946, Molotov complained bitterly to Byrnes:

There is no corner of the world in which the USA cannot be seen. The US has air bases everywhere: in Iceland, Greece, Italy, Turkey, China, Indonesia and other places and an even greater number of air and naval bases in the Pacific Ocean. The US maintains its troops in Iceland despite the protests of the Icelandic government, also in China, while the USSR's troops have been withdrawn from China and other foreign territories. This is evidence of a real expansionism and expresses the striving of certain American circles towards an imperialist policy. ${ }^{27}$

Byrnes replied that there was 'no region in the world in which the USSR had not put forward its claims', but from Moscow's point of view the landscape of the postwar world was dominated not by Soviet expansionism but by AngloAmerican globalism.

Soviet anxieties were further intensified by President Truman's speech to the US Congress in March 1947 announcing substantial American aid to Greece (and Turkey) and calling for a global defence of the free world in the face of threats from 'armed minorities and or by outside pressures'. In September 1947 the Soviet riposte was delivered by Zhdanov in his 'two-camps' speech at the founding conference of the Cominform, which linked events in Greece to US striving for world supremacy. By this time the Soviets had joined communist Albania, Bulgaria and Yugoslavia in aiding the Greek partisans directly, ${ }^{28}$ although Stalin remained skeptical about the KKE's armed strategy. In 1948 he reacted strongly against Bulgarian and Yugoslav plans to form a Balkan Federation involving territories controlled by communist partisans in Greece, telling a delegation from the two countries that such a move was too

26 See, for example, V.M. Molotov, Problems of Foreign Policy: Speeches and Statements (April 1945-November 1948) (Moscow 1949).

27 G.P. Kynin and J. Laufer (eds), SSSR $i$ Germanskii Vopros, 1941-1949, vol. 2 (Moscow 2000), document 112 .

28 See A.A. Ulunian, 'The Soviet Union and "the Greek Question”, 1946-53', in F. Gori and S. Pons (eds), The Soviet Union and Europe in the Cold War, 1943-1953 (London 1996). 
provocative and played into the hand of Western warmongers. ${ }^{29}$ In his diary Dimitrov recorded Stalin as saying:

\begin{abstract}
Recently I started to doubt that the partisans could win. If you are not sure the partisans would win, the partisan movement should be restricted. The Americans and the English have a very strong interest in the Mediterranean. They would like to have their bases in Greece. They would use all possible means to support a government that would be obedient. This is an international issue of great importance. If the partisan movement is halted, they will have no excuse to attack you [Yugoslavia and Bulgaria - GR]. It is not so easy to start a war now, when they lack the pretext that you are organizing civil war in Greece. If you are confident that the partisans have good chances of winning, it is a different matter. But I have some doubts about this. ${ }^{30}$
\end{abstract}

Stalin's doubts were vindicated by the events of summer 1949, when ELAS suffered a major defeat in northern Greece and was forced to retreat into Albania. Shortly after, in September 1949, Zachariadis visited Stalin at his holiday home in Gagra, Georgia. After three days of discussions the Greek communist leader emerged with a policy document, endorsed by Stalin, which called off the armed struggle and directed a strategy based on political and economic agitation. ${ }^{31}$

The origins of the postwar crisis over the withdrawal of Soviet troops from Iran lay in the Allied occupation of the country during the Second World War. In August 1941 British and Soviet forces entered the country and overthrew Iran's pro-German government. The aim was to secure control of Iranian oil fields and protect Allied supply routes to the USSR. Soviet troops occupied northern Iran and the British the south, while the Iranians remained nominally in control of the centre of the country. Under a January 1942 Treaty of Alliance with Iran, the British and the Soviets pledged to withdraw their forces six months after the end of the war with 'Germany and its associates' (later interpreted to include Japan). The USA was not a formal party to the treaty, or to the occupation of Iran, but in 1942 its troops entered the country in order to protect its Lend-Lease convoys to the Soviet Union. ${ }^{32}$

The Soviets had long coveted an Iranian oil concession and they took advantage of the occupation to pursue this goal. In January 1944 the Commissariat of Oil reported on the results of geological surveys that showed there were rich oil fields in northern Iran. In August 1944 Lavrentii Beria, the Soviet security chief, proposed to Stalin and Molotov a Soviet oil concession in the areas occupied by the Red Army. The negotiation of such concessions was the task of a foreign commissariat delegation to Tehran in September-October 1944. Negotiations broke down, however, when the Iranians decided not to grant any

29 'Na Poroge Pervogo Raskola v "Sotsialisticheskom Lagere"', Istoricheskii Arkhiv 4 (1997).

30 Dimitrov Diary, op. cit., entry for 10 February 1948, 441.

31 RGASPI, F17, Op.166, D.807, LL.18-24.

32 S.L. McFarland, 'A Peripheral View of the Origins of the Cold War: The Crisis in Iran, 19411947’, Diplomatic History 4(4) (Fall 1980). 
more oil concessions until the withdrawal of all Allied troops after the war. ${ }^{33}$ The Soviets responded to this rebuff by sponsoring anti-government demonstrations by its supporters in Iran. ${ }^{34}$

When the war in Europe ended, the Iranian government requested an immediate Allied troop withdrawal. The Soviets ignored this request, and on 25 May 1945 Deputy Foreign Commissar Sergey Kavtaradze, head of the Soviet negotiating team to Tehran, proposed to Molotov and Stalin that the Red Army should not withdraw from Iran until an oil concession had been extracted or a joint stock company controlled by Moscow created. ${ }^{35}$ At this point Moscow's need to pressure Tehran into granting an oil concession intersected with nationalist lobbying for the unification of Soviet Azerbaijan with southern Azerbaijan - the area of northern Iran occupied by the Red Army. In April 1945 Mir Bagirov, the communist chief of Soviet Azerbaijan, drafted a plan for the unification of 'southern Azerbaijan with Soviet Azerbaijan, or the formation of an independent southern Azerbaijani People's Republic, or the establishment of an independent bourgeois-democratic system or, at least, cultural autonomy in the framework of the Iranian state'. ${ }^{36}$ In early June 1945 Bagirov, along with Molotov and Kavtaradze, was directed by the Politburo to evaluate the feasibility of organizing separatist movements in southern Azerbaijan and other provinces of northern Iran. On 6 July the Politburo passed a resolution authorizing the establishment of such separatist movements, including the organization of a Democratic Party of Azerbaijan that would agitate for autonomy, albeit within the framework of the existing Iranian state. ${ }^{37}$

The Azerbaijani Democratic Party (DPA) was formed in September 1945, headed by Seyid Pishavari, a former communist and a popular left-liberal journalist. Aided by the Soviets, the DPA forcibly took control of southern Azerbaijan. A party assembly was convened in October, followed by elections to an Azerbaijan National Congress in November and local parliamentary-type elections in December.

In response to these developments, Tehran proposed to send additional troops and police into Soviet-occupied northern Iran. On 20 November the Soviet General Staff wrote to Stalin proposing to comply with the Iranian request. They were overruled by Stalin, however, and two days later the Red Army was ordered to resist any attempts to introduce troops into south Azerbaijan. ${ }^{38}$ Tehran's other tactic was to internationalize the crisis by appealing for British and American support and by threatening to take the matter up at the United Nations. The Soviets responded to this pressure by insisting,

33 N.I. Yegorova, The 'Iran Crisis' of 1945-1946: A View from the Russian Archives, Cold War International History Project Working Paper No. 15 (May 1996), 2-6.

34 Hasanli, At the Dawn of the Cold War, op. cit., 52.

35 Yegorova, The 'Iran Crisis', op. cit., 8.

36 F.S. Raine, 'Stalin and the Creation of the Azerbaijan Democratic Party in Iran, 1945', Cold

War History 2(1) (October 2001), 6.

37 Hasanli, At the Dawn of the Cold War, op. cit., 64-6.

38 Gasanly, 'Iranian Azerbaijan', op. cit., pt 1, 13. 
firstly, that the movement for Azerbaijani autonomy was an internal Iranian matter and, secondly, that their troops would be withdrawn, in accordance with the 1942 treaty, six months after the end of the Second World War (since Japan had formally surrendered on 2 September, that meant 2 March 1946).

At the Moscow Foreign Ministers' meeting in December 1945 it was agreed that, while troop withdrawals from Iran and other countries would not be formally discussed, there could be informal talks. In this context Byrnes and Bevin raised the Iranian crisis with Molotov on a number of occasions, but to little or no effect. ${ }^{39}$ Bevin and Byrnes also had the opportunity to discuss the Iranian crisis with Stalin, who assured them that the Soviet Union had no territorial claims against Iran and had no intention of incorporating any part of it into the USSR or of undermining the country's sovereignty. ${ }^{40}$

The Soviets tried to block discussion of the Iranian crisis at the UN, but at the end of January 1946 the Security Council, meeting in London, heard statements from Soviet and Iranian representatives. The upshot was a Security Council resolution urging bilateral Soviet-Iranian negotiations. This suited the Soviets, since a new government headed by Qavam as-Saltanah had just come to power in Iran. Qavam was elected Premier with the support of the Tudeh Party - a front for the Iranian communists - and he was seen by the Soviets as a man they could do business with. On 19 February Qavam arrived in Moscow for talks and indicated that he might be willing to compromise on the question of an oil concession. In response, the Soviets proposed (i) that southern Azerbaijan should be granted autonomy; (ii) the establishment of a Soviet-Iranian oil company in northern Iran (with control split 51-49 in Moscow's favour); and (iii) gradual withdrawal of Soviet troops when order had been restored in northern Iran. These terms were not acceptable to Qavam, but he softened his position when the Soviets threatened to withdraw the offer of a joint Soviet-Iranian enterprise and return to the demand for a straightforward oil concession. Qavam left Moscow on 5 March, but discussions continued in Tehran and by early April the two sides had agreed that the Red Army would withdraw by early May, that there would be a Soviet-Iranian oil company (subject to parliamentary approval) and that there would be concessions to Azerbaijani demands for autonomy. ${ }^{41}$

During his discussions with Qavam, Stalin put it to the Iranian leader that the retention of Soviet troops in southern Azerbaijan would facilitate the stabilization of his power position in Tehran. Qavam responded that he might be removed if the Soviet troops remained. It may be that this was the calculation that prompted Stalin to authorize, on 24 March, the pullout of Soviet troops the redeployment to the Baku Military District to be completed by late April or early May. ${ }^{42}$

39 Documents on British Policy Overseas (hereafter 'DBPO'), series 1, vol. 2, (HMSO London 1985), documents 289, 300, 337, 341, 343, 349, 352, 353.

40 Ibid., document 308, 780 .

41 Hasanli, At the Dawn of the Cold War, op. cit., ch.11, 267.

42 Gasanly, 'Iranian Azerbaijan', op. cit., pt 1, 17; pt 2, 6. 
DPA leader Pishavari reacted negatively to the news of the deal, telling his Soviet interlocutors that Qavam could not be trusted, that the Iranian promise of an oil concession lacked substance, and that the Red Army's withdrawal from southern Azerbaijan would result in the violent crushing of the democratic movement. ${ }^{43}$ Stalin was informed of Pishavari's comments and was moved to reply. In a letter dated 8 May 1946, Stalin told Pishavari that the 'revolutionary demands of Azerbaijan' could not be fulfilled, because there was no revolutionary crisis in Iran. Stalin conceded that the Azerbaijani movement could have succeeded if the Red Army had remained in Iran, but that was not possible

because the presence of Soviet troops in Iran undercut the foundations of our liberationist policies in Europe and Asia. The British and Americans said to us that if Soviet troops could stay in Iran, then why could not British troops stay in Egypt, Syria, Indonesia, Greece, and also American troops - in China, Iceland, in Denmark. Therefore we decided to withdraw troops from Iran and China, in order to seize this tool from the hands of the British and Americans, to unleash the liberation movement in the colonies and thereby to render our liberationist policy more justified and efficient.

Stalin argued further that Qavam was in conflict with 'Anglophile circles in Iran who represent the most reactionary elements', and that 'we should use this conflict to wrench concessions from Qavam, to give him support, to isolate the Anglophiles, and to create some basis for the further democratization of Iran'. The alternative, Stalin pointed out, was to split with Qavam and 'thereby ensure a victory of Anglophile reactionaries'. ${ }^{44}$

Stalin's ideological justification for the deal with Qavam was similar to his rationale for communist postwar strategy in Europe: the time was ripe for reform not revolution, it was necessary to isolate reactionary elements, and democratization was the way forward for the progressive movement. It seems clear, nonetheless, that the primary reason for the withdrawal of Soviet troops was not revolutionary strategy but the oil deal with Qavam and the calculation that he could be trusted and/or pressured into keeping his side of the bargain. Did Stalin also buckle under Western diplomatic pressure? The old Cold War literature, such as Kuniholm's book, focused on the impact of Iranian lobbying at the UN in the period January-March $1946,{ }^{45}$ but there is no evidence that this influenced Soviet behaviour and it is difficult to imagine Stalin being moved by it. That is not to say that Stalin was not mindful of the broader consequences of his actions in relation to Iran. As his letter to Pishavari indicates, he was concerned about setting a precedent for delays in the withdrawal of Western troops from various countries. This concern was connected to growing fears in

43 Hasanli, At the Dawn of the Cold War, op. cit., 257-60.

44 The full text of an English translation of Stalin's letter may be found in Yegorova, The 'Iran Crisis', op. cit., 23-4. The Russian original may be found in N.I. Yegorova, “"Iranskii Krizis" 1945-1946gg: Po Rassekrechnnym Arkhivnym Dokumentam', Novaya i Noveishaya Istoriya 3 (1994), 40-2.

45 Kuniholm, Origins of the Cold War, op. cit., 304-42. 
Moscow that the Grand Alliance was being undermined by internal political developments in Britain and the United States. From the failure of the London CFM meeting onwards, there was a growing perception in Moscow that reactionary, anti-Soviet forces were on the rise in the West. ${ }^{46}$ These fears had been allayed somewhat by the success of the Moscow Foreign Ministers' meeting in brokering a deal on Western recognition of the Bulgarian and Romanian governments - an agreement that made it possible to continue negotiations about the peace treaties for the former Axis states. But the climax of the Iranian crisis coincided with Churchill's 'Iron Curtain' speech in Fulton, Missouri on 5 March 1946. A few days later Stalin denounced Churchill as a warmonger in a front-page interview with Pravda. It may be, therefore, that Stalin was anxious to avoid actions in Iran that would give more ammunition to Western warmongers and this reinforced his inclination to take the deal with Qavam.

Another factor weighing in favour of a compromise with Qavam was the course of internal political developments in southern Azerbaijan. Moscow favoured autonomy for southern Azerbaijan, but the political dynamic there had grown increasingly separatist and was threatening to get out of hand. Stalin sponsored the DPA as a political tactic; it is highly unlikely that he had any interest in the partition of Iran in the form of a breakaway republic of southern Azerbaijan or its unification with Soviet Azerbaijan. Such a development would have had untold consequences - the destabilization of Iran, the complete breakdown of Soviet-Iranian relations, and political-ethnic upheavals not just in Azerbaijan but in neighbouring Georgia and Armenia. From Stalin's point of view, the deal with Qavam was a convenient device to curb the radical tendencies of the DPA. ${ }^{47}$

Soviet troops had evacuated Iran by early May (the Americans had left in December, the British by the 2 March deadline), and at first Qavam kept to his side of the bargain. In June he signed an autonomy agreement with the DPA. In August he admitted three Tudeh ministers into his government. By October, however, the communist ministers had been excluded from government and Qavam was preparing to send troops into southern Azerbaijan to restore order and central authority, so that national elections could be held. The Soviets urged Qavam not to send in the troops, but acquiesced when he did so in December 1946. On 11 December Stalin sent this message to Pishavari:

\footnotetext{
The prime minister is entitled to send troops to all parts of the country, including Azerbaijan. For this reason it would be inexpedient and useless to go on with armed resistance. You had better announce that you do not object to bringing governmental forces into Azerbaijan with the purpose of maintaining law and order in the region during elections. You must link this
}

46 See V. Pechatnov, 'Exercise in Frustration: Soviet Foreign Propaganda in the Early Cold War, 1945-1947', Cold War History 1(2) (January 2001).

47 See S. Savranskaya and V. Zubok, 'Cold War in the Caucasus: Notes and Documents from a Conference', Cold War International History Project Bulletins nos 14-15; and idem, 'From the Baku Archives', Bulletins nos 12-13. 
step to your desire to ensure the integrity of the Iranian peoples, their freedom and independence. $^{48}$

Stalin's words must have rung particularly hollow to Pishavari, who had predicted this denouement in April. By the end of 1946 Tehran had retaken control of southern Azerbaijan and violently suppressed the DPA, while Pishavari and the other Azeri leaders fled into exile in the USSR. It is reported that some 30,000 supporters of the DPA lost their lives at the hands of the Iranian authorities. ${ }^{49}$

The Soviets continued to hope the oil deal would hold, but in October 1947 the Iranian parliament voted it down and around the same time ratified a decision to sign a military agreement with the United States. Stalin's policy in Iran had failed comprehensively, save in one respect: Soviet Azerbaijan had been protected from the nationalist contagion of an independent or autonomous southern Azeri republic.

For both the Allies and the Axis, Turkey was the most sought-after neutral state of the Second World War. However, as Keith Sainsbury aptly put it, Turkey was 'an ally which was often wooed, but never won'. ${ }^{50}$ Moscow joined in the pursuit of a Turkish alliance, but reluctantly and with deep skepticism. Indeed, until the end of 1942 Moscow's main concern was not wooing the Turks into alliance but preventing their entry into the war on the German side. Shortly after Turkey declared its neutrality on 26 June 1941, Stalin told the leaders of the Armenian and Azerbaijan Communist Parties that 'you are far removed from the front yet your zone is no less dangerous. We cannot rely on Turkey's neutrality. ${ }^{, 51}$ In July 1942, as the German armies advanced to Stalingrad and Baku, the Soviet envoy to Turkey, S.A. Vinogradov, told Dimitrov:

In his estimation, the Turks will not enter the war, even if the Germans take Suez. It will be another matter if the Germans succeed in reaching the Caucasus... They will try all sorts of maneuvers until the outcome of the current major battles on the Soviet-German front becomes clear... The Turks are afraid of the Germans now; they are afraid of $u s$ as regards the future. Their internal sentiments could be characterized as '[Send] the Germans to the hospital, Russians to the cemetery. 52

On 29 July 1942 Molotov warned Dimitrov that 'Turkey's position remains uncertain. Must be on our guard. There is no ruling out that the Turks could even turn against us.... 53

With the Soviet victory at Stalingrad in early 1943, the danger of a Turkish alliance with the Axis passed and Moscow reconsidered the prospects for

48 Hasanli, At the Dawn of the Cold War, op. cit., 370.

49 Gasanly, 'Iranian Azerbaijan', op. cit., pt 2, 13.

50 K. Sainsbury, The Turning Point: Roosevelt, Stalin, Churchill and Chiang Kai-Shek (Oxford 1986), 24.

51 Gasanly, 'The "Turkish Crisis"', op. cit., pt 1, 116.

52 Dimitrov Diary, op. cit., 229.

53 Ibid., 233. 
Turkey entering the war on the Allied side. Following the Adana Conference of 30-31 January, Churchill informed Stalin that his meetings there with Turkish leaders had convinced him that Turkey would enter the war before the end of 1943 and he asked Stalin to consider making some friendly gestures towards Ankara. On 6 February Stalin replied, pointing out that Turkey's position was 'rather ticklish', since the country was linked by friendship treaties to Germany as well as Britain and the USSR. But if the Turks wanted better relations, the Soviet Union would 'meet them halfway'. ${ }^{54}$ An exchange of friendly diplomatic noises between Ankara and Moscow followed, but further developments were stalled by Turkey's unwillingness to abandon its strict neutrality. In response, the Soviets began a press campaign against Turkey, the main theme being a sharp critique of Turkish neutrality, with Ankara's policy depicted as proGerman. ${ }^{55}$ In July 1943 Vinogradov advised Moscow to put pressure on Turkey to gain access to military bases for an Allied campaign in the Balkans. Even if the pressure had no result, argued Vinogradov, it would add to the list of grievances that could be leveled against Turkey at a later date. $^{56}$

At the Moscow Conference of Foreign Ministers in October 1943 the Soviets submitted a proposal that Turkey should enter the war against the Axis before the end of the year. ${ }^{57}$ Stalin explained to Eden:

\begin{abstract}
Next year the participation of Turkey in the war will not be necessary. At the present time Turkish neutrality... helps Hitler by protecting his Balkan flank. If Turkey entered the war this year the Germans would not be able to resist since they do not have sufficient reserves. Turkey aspires to participate in the peace conference and has its claims. It is necessary for her to contribute to victory in order to merit participation in the peace conference. ${ }^{58}$
\end{abstract}

At the conference it was agreed that Turkey would be approached to enter the war before the end of 1943 and, as a first step, would be asked to open its bases to use by Allied military forces. ${ }^{59}$

Discussions on Turkey continued at the Tehran conference. At the first plenary session on 28 November 1943, Stalin was skeptical: 'I doubt that Turkey will enter the war. She will not enter the war, no matter what pressure we exert

54 Stalin's Correspondence with Churchill, Atlee, Roosevelt and Truman, 1941-1945 (London 1958), vol.1, document 111.

55 See two articles by N. Vasil'ev, published in Voina i Rabochii Klass: 'Komy na pol'zu neitralitet Turtsii?' (no. 7, 1943) and 'Eshche paz o neitralitete Turtsii' (no. 10, 1943).

56 Gasanly, "The "Turkish Crisis"', op. cit., pt 1, 118.

57 Moskovskaya Konferentsiya Ministrov Inostrannykh Del SSSR, SShA i Velikobritanii (Moscow 1984), 122, 219, and document 58.

58 Ibid., 123.

59 Ibid., 373, n. 100. In an internal briefing note prior to the conference the emphasis was very much on an immediate and definite Turkish entry into the war, and opposition to a graduated approach, such as the establishment of Allied (i.e. Western) military bases in Turkey. (AVPRF, F.06, Op.5b, Pap.41, D.20, LL.29-30). 
on her. ${ }^{60}$ Stalin also made it clear that Overlord - the Allied invasion of northern France - should be the Anglo-American military priority in 1944, not operations relating to Turkey. Nevertheless, Stalin remained committed to the principle of Turkish entry into the war and was even prepared to state that the Soviet Union would declare war on Bulgaria should a TurkishBulgarian conflict develop as a consequence of Turkey declaring war on Germany. ${ }^{61}$

At the second plenary session on 29 November 1943, Churchill said that 'if Turkey does not accept the proposal to enter the war this could have serious political consequences for Turkey and affect her rights in relation to the Bosporus and the Dardanelles. ${ }^{62}$ Stalin did not comment, but at lunch the next day he was drawn by Churchill into a discussion of the Straits issue, which began with the British premier remarking that Russia needed access to an ice-free port. Stalin agreed, but said the question required further discussion. Churchill continued that 'earlier the English were against the Russians having access to warm waters, but now they had no such objections'. Stalin replied:

If now there were no objections it was necessary to reexamine the regime of the Turkish Straits. A big country such as Russia found itself locked in the Black Sea, with no means of exit. The Straits regime was first regulated by the Sevres agreement [of 1920], then the Lausanne agreement [of 1923], and finally the convention concluded in Montreux [1936]. All this time the English wanted to strangle Russia and if now the English did not want to strangle Russia any more then it was necessary to alleviate the Straits regime.

Churchill responded that, while he agreed with Stalin, the immediate issue was Turkey's entry into the war. Stalin concurred and said there would be time in the future to consider the question of ports and the Straits. ${ }^{63}$

Stalin's prognosis concerning Turkey's non-entry into the war proved to be correct and by summer 1944 he had given up on the Turks. 'In view of the evasive and vague attitude which the Turkish Government has assumed in relation to Germany', he messaged Churchill on 15 July, 'it is better to leave Turkey to herself and to refrain from any further pressure on her. This implies, of course, that the claims of Turkey, who has evaded fighting Germany, to special rights in post-war affairs, will be disregarded. ${ }^{64}$

It is apparent that Stalin was now thinking more about Turkey's postwar situation than any contribution it might make to the defeat of the Axis; above all, he was thinking about the revision of the Montreux Convention of 1936, under the terms of which Turkey controlled shipping through

60 Tegeranskaya Konferentsiya Rykovoditelei Trekh Derzhav - SSSR, SShA i Velikobritanii (Moscow 1984), 89.

61 RGASPI F.0555, Op.1, D.24, L.50. This promise by Stalin was obfuscated in the published Soviet record of Tehran.

62 Tegeranskaya Konferentsiya, op. cit., 113.

63 Ibid., 126-7. This exchange was selected for inclusion in a summary of the conference prepared for (and annotated by) Stalin: RGASPI F.558, Op.11, D.234, L.101.

64 Stalin's Correspondence, op. cit., vol. 1, 238. 
the Black Sea Straits. The USSR was a signatory to the agreement, but Stalin had long sought its amendment or replacement, with a view to securing more Soviet control of the Straits regime. On 9 October 1944 Stalin told Churchill that 'under the Montreux Convention Turkey has all the rights to the Straits, while the Soviet Union has very few rights... it was necessary to discuss the question of revising the Montreux Convention, which did not correspond to the current situation at all.' In response, Churchill reiterated his support for warm seas access for Russia, but asked what Stalin had in mind. Stalin was unable to say what changes to Montreux he wanted, but he successfully pressed Churchill to agree that revision was necessary. ${ }^{65}$ According to the British record of this discussion Stalin also said:

It was quite impossible for Russia to remain subject to Turkey, who could close the Straits and hamper Russian imports and exports and even her defence. What would Britain do if Spain or Egypt were given this right to close the Suez Canal, or what would the United States Government say if some South American Republic had the right to close the Panama Canal? ${ }^{66}$

Such references to the Suez and Panama canals cropped up again and again in Soviet-Western discussions of the Straits, including at the Yalta conference in February 1945, when Stalin formally raised the question of revising Montreux and suggested that the matter be considered by the American, British and Soviet foreign ministers. ${ }^{67}$

After the Yalta conference, however, Soviet policy on Turkey took a distinctly unilateralist turn. On 19 March Molotov announced that the USSR would not renew the 1925 Soviet-Turkish Treaty of Friendship and Neutrality when it expired in November 1945. The treaty, said the Soviet statement, 'no longer corresponded to the new situation and needed serious improvement.' 68 Behind Moscow's move were a series of internal Foreign Ministry documents dating from late 1944 and early 1945 considering how best to progress Soviet policy on the reform of the Straits regime. ${ }^{69}$ The conclusion drawn was that the way forward was bilateral negotiations with Turkey, and the denunciation of the Soviet-Turkish pact was seen as a way of opening such negotiations and of putting pressure on the Turks in advance of talks.

The Turkish response to the Soviet declaration was to seek negotiations about a new treaty. On 7 June the Turkish ambassador in Moscow, Salim Sarper, met Molotov. Sarper told Molotov that, while Turkey would like to sign a mutual assistance treaty with the Soviet Union, it would be difficult to

65 RGASPI F.558, Op. 11, D. 283, LL.10-11.

66 British record, reproduced in J.M. Siracusa, 'The Meaning of Tolstoy: Churchill, Stalin and the Balkans, Moscow, October 1944', Diplomatic History (Fall 1979), 449.

67 Krymskaya Konferentsiya Rukovoditelei Trekh Souznykh Derzhav - SSSR, SShA i Velikobritanii (Moscow 1979), 201-2.

68 Vneshnyaya Politika Sovetskogo Souza v Period Otechestvennoi Voiny (Moscow 1947), 146.

69 These internal documents are cited in detail in Dzh. Gasanly [J. Hasanli], SSSR-Turtsiya, op. cit., 124-43. 
change the Straits regime because other states were party to that agreement. But, Sarper pointed out, under the terms of a Soviet-Turkish mutual assistance treaty Turkey would be bound to defend the Straits and the Black Sea from encroachments by common enemies. In response, Molotov asked who would object if the Soviet Union and Turkey came to an agreement on the Straits? Molotov went on to say that before there could be a new Soviet-Turkish treaty the territorial pretensions of Armenia and Georgia against Turkey would have to be satisfied. Molotov was referring to the provinces of Kars and Ardahan. These were areas of Eastern Turkey with Armenian and Georgian populations which had been part of the Tsarist Empire from 1878 until 1921, when a Soviet-Turkish treaty transferred the two districts to Turkey. If agreement could not be reached on the territorial issue, said Molotov, then negotiations between the USSR and Turkey would have to be restricted to the Straits issue. Molotov met with Sarper again on 18 June and made the same point: if Turkey could not satisfy Soviet territorial aspirations, there could be no mutual assistance pact between the two states, but there could be negotiations about the Straits. In both conversations Molotov pointed to the comparison with SovietPolish relations. In 1921 the Soviet Union had been weak and had been forced to concede territory to Poland. The same had happened in relation to Turkey. But whereas Soviet-Polish differences had been resolved by redrawing the border, Armenia and Georgia's territorial claims remained unsatisfied. ${ }^{70}$

Why Molotov chose to make these territorial demands at this particular point in time is not entirely clear. It may be that Stalin's personal preferences were important. In November 1940 Stalin told Dimitrov:

As regards Turkey, we demand a base to ensure that the straits cannot be used against us. The Germans would evidently like the Italians to become masters of the straits, but they themselves cannot fail to acknowledge our prior interests in that region. We shall drive the Turks into Asia. What is Turkey? There are two million Georgians there, one and half million Armenians, a million Kurds, and so forth. The Turks only amount to six or seven million. ${ }^{71}$

Then there is Khrushchev's memoir account of the origins of the demand for Kars and Ardahan:

At one of those interminable 'suppers' at Stalin's [dacha], Beria started harping on how certain territories, now part of Turkey, used to belong to Georgia and how the Soviet Union ought to demand their return... Beria kept bringing this subject up, teasing Stalin with it, goading him into doing something. He convinced Stalin that now was the time to get those territories back. He argued that Turkey was weakened by World War II and wouldn't be able to resist. Stalin gave in and sent an official memorandum to the Turkish government pressing our territorial claims. ${ }^{72}$

70 The content of the two conversations, as recorded by the Soviets, is recounted in detail by Gasanly [Hasanli], SSSR-Turtsiya, op. cit., 162-74.

71 Dimitrov Diary, op. cit., 137.

72 Khrushchev Remembers: The Last Testament (London 1974), 295-6. 
Finally, there is the evidence from Molotov's conversations with the Soviet journalist Felix Chuev in the 1970s and 1980s:

I recall a story told by A. Mgeladze [leader of the Georgian Communist Party], supplemented by Molotov.

It's about a map with the new borders of the USSR that was brought after the war to Stalin's dacha ... 'Let's see what we have here... Everything is all right to the north. Finland has offended us, so we moved the border from Leningrad. Baltic States - that's age-old Russian lands! - and they are ours again. All Belorussians live together now. Ukrainians together. Moldavians together...the Kurile Islands belong to us now, Sakhalin is completely ours... And Port Arthur... and Dairen ... and the Chinese Eastern railway is ours. China, Mongolia - everything is in order. But I don't like our border right here!' Stalin said and pointed south of the Caucasus. ${ }^{73}$

The Khrushchev and Chuev stories are probably apocryphal, but they do draw attention to the strong ethnic element of Soviet foreign policy during the Second World War. In this regard Moscow's territorial demands on Turkey may be seen as part of a pattern of Soviet ethnic expansion that had begun with the Red Army's invasion of eastern Poland in September 1939. That action was justified on the grounds that the Western Belorussian and Western Ukrainian lands occupied by the Red Army were historically and ethnically part of the Soviet Union. Similar reasons were advanced for the demand in June 1940 that Romania concede Bessarabia and Bukovina. The incorporation of the Baltic States in July-August 1940 was more ideological than ethnic, ${ }^{74}$ but their recent history as provinces of Tsarist Russia was important, too. During the war Stalin was adamant that the USSR's postwar border with Poland would run along the 'Curzon Line' - the ethnographical frontier recommended by a commission of the Paris Peace Conference in 1919. When Churchill suggested that conceding the city of Lvov to postwar Poland would be a good gesture to the Poles, Stalin replied that the Ukrainians would never forgive him. At the end of the Second World War, Stalin negotiated the transfer of Carpathian-Ukraine from Czechoslovakia. He later commented:

In their times, in the 13th century, the Russians lost the Trans-Carpathian Ukraine and from that time they always dreamt of recovering it. Thanks to our correct policy, we succeeded in recovering all Slavic - Ukrainian and White Russian - lands and to realize the age-old dreams of the Russian, Ukrainian and White Russian people. ${ }^{75}$

There was also a more immediate ethnic context to the demand for the return of Kars and Ardahan: Molotov's raising of Soviet claims on Turkey coincided with moves by Stalin to sponsor the separatist movement in Iranian Azerbaijan. Just as the Red Army's occupation of northern Iran during the war had encouraged Azeri nationalist hopes, so the denunciation of the Soviet-Turkish treaty

73 Ivan R. Dee, Molotov Remembers (Chicago 1999), 8.

74 See G. Roberts, 'Soviet Policy and the Baltic States, 1939-1940', Diplomacy and Statecraft 6(3) (November 1995).

75 Cited by E. van Ree, The Political Thought of Joseph Stalin (London 2002), 232. 
had raised expectations in Armenia and Georgia about the reunification of their national territories. ${ }^{76}$ But, as Molotov's talks with Sarper indicated, Moscow's priority was the renegotiation of the Straits regime - even if that meant leaving ethnic and territorial disputes unresolved.

At the Potsdam Conference in July 1945, Stalin and Molotov mentioned their territorial demands on Turkey, but the formal Soviet proposal was restricted to joint control of the Straits, including provision for military bases. ${ }^{77}$ While Truman and Churchill were prepared to contemplate changes in the Straits regime, the conference protocol restricted itself to the statement that Montreux should be revised as 'not meeting present-day conditions' ${ }^{78}$

Soviet-Western exchanges on the Straits continued at the London CFM meeting. On 23 September 1945 Molotov pointed out to Bevin that during the First World War Britain had been prepared to concede Constantinople to Tsarist Russia, and that he could not understand the resistance to the Soviet demand for bases. ${ }^{79}$

Within Turkey, the Soviet demand for territorial concessions as well as control of the Straits inflamed political and public opinion. In December 1945 there were student riots in Istanbul and violent attacks on pro-Soviet newspapers and organizations. In response, Vinogradov proposed that Moscow issue a statement denouncing Turkish fascism, inform the British and Americans that it might have to take steps to strengthen its security, and announce that garrisons on the Soviet-Turkish border would be strengthened. Moscow did issue a protest statement on anti-Soviet manifestations in Turkey, but privately Vinogradov was upbraided for his extremist suggestions:

Your suggestions are completely ill-advised and unacceptable...we cannot make official statements to the Turkish government about the rise of fascism in Turkey because this is the Turks' internal affair. Your suggestion that we should make a declaration to the British and Americans cannot be taken seriously - it is unacceptable. Sabre-rattling might be taken for a provocation. Your suggestion that TASS should publish information... [that] the Soviet government [had] decided to reinforce its garrisons along the Soviet-Turkish border is flippant and verges on childishness. We equally cannot accept your suggestion that your contacts with the Turks should be discontinued. You should keep your head and should not forward hasty suggestions that might cause political complications for our state. ${ }^{80}$

In December 1945 Stalin reiterated Soviet demands to Bevin at the Foreign Ministers' Conference in Moscow, but said that 'all talk of war against Turkey was rubbish'. ${ }^{81}$ In April 1946 Stalin told US Ambassador Bedell Smith that

76 See A.A. Ulunian, 'Soviet Cold War Perceptions of Turkey and Greece, 1945-1958', Cold War History 3(2) (January 2003).

77 Berlinskaya (Potsdamskaya) Konferentsiya Rukovoditelei Trekh Souznykh Derzhav - SSSR, SShA $i$ Velikobritanii (Moscow 1980), document 63.

78 Ibid., 444.

79 DBPO, 317-18.

80 Gasanly, "The "Turkish Crisis", op. cit., pt 1, 126.

81 Ibid., 781. 
I have assured President Truman and have stated publicly that the Soviet Union has no intention of attacking Turkey... but Turkey is weak, and the Soviet Union is very conscious of the danger of foreign control of the Straits, which Turkey is not strong enough to protect. The Turkish Government is unfriendly to us. That is why the Soviet Union has demanded a base in the Dardanelles. It is a matter of our own security. ${ }^{82}$

Notwithstanding such reassurances, there were growing worries in the West that the USSR was preparing for war with Turkey over the Straits issue, or at least was intent on using the threat of Soviet military power to back its diplomatic demands. ${ }^{83}$ While the idea that Stalin contemplated war against Turkey in 1946 seems far-fetched, it is plausible that Stalin used Red Army maneuvers on the border to ratchet up the tension and influence the Turks. However, the course of the Soviet-Turkish crisis over the Straits when it finally broke in summer 1946 does not suggest that Stalin was determined to press his demands very far.

On 7 August - more than a year after Molotov's meetings with Sarper - the USSR sent Ankara a diplomatic note on the revision of the Montreux Convention. Following a critique of Turkey's operation of the Straits regime during the war, the note proposed that the Straits should: (i) always be open to merchant shipping; (ii) always be open to the warships of Black Sea powers; (iii) be closed to the warships of non-Black Sea powers, except in special circumstances; (iv) be under the control of Turkey and other Black Sea powers; and $(\mathrm{v})$ be jointly defended by the Soviet Union and Turkey. ${ }^{84}$ The note itself was presented as building on existing proposals for the revision of Montreux, including an American diplomatic note issued on 2 November 1945 - a point emphasized in a moderate and conciliatory Izvestiya article on the subject. ${ }^{85}$ On 19 August 1946, however, the United States challenged Moscow's contention that the Straits regime was an exclusive concern of Black Sea powers and called for a multilateral conference to revise Montreux. The British expressed similar views to Moscow two days later. On 22 August Turkey replied, echoing the British and American responses and stating in addition that the Soviet demand for joint defence of the Straits was incompatible with the maintenance of Turkish sovereignty and security. ${ }^{86}$ On 24 September Moscow responded with a memorandum that reiterated the special rights of Black Sea powers in relation to the Straits and denied that the Soviet proposals threatened or undermined Turkish sovereignty or security. ${ }^{87}$ On 9 October the British and

82 W. Bedell Smith, Moscow Mission, 1946-1949 (London 1950), 41-2.

83 See E. Mark, 'The War Scare of 1946 and Its Consequences', Diplomatic History 21(3) (Summer 1997).

84 Vneshnyaya Politika Sovetskogo Souza, 1946 god (Moscow 1952), 167-70.

85 'The Problem of the Black Sea Straits', Izvestiya article translated and published in Soviet News, 22 August 1946.

86 A.R. De Luca, 'Soviet-American Politics and the Turkish Straits', Political Science Quarterly 92(3) (Autumn 1977), 519.

87 Vneshnyaya Politika Sovetskogo Souza, 1946 god (Moscow 1952), 193-202. 
Americans reiterated their position, and on 18 October the Turks restated their position. ${ }^{88}$

The USSR never replied to the Turkish note of 18 October and took no further action in relation to the Straits issue, notwithstanding proposals from Soviet diplomats in Ankara to intensify the 'war of nerves' with Turkey. One of their suggestions was the denunciation of the 1921 treaty that had transferred Kars and Ardahan to Turkey, another was an ultimatum on the Straits to Ankara and a break in diplomatic relations if it was not fulfilled. Stalin's diplomats also proposed bypassing Turkey and conducting direct negotiations with Britain and the United States about the Straits. ${ }^{89}$ None of these hardball tactics were adopted by Stalin. When a new Soviet ambassador was appointed to Turkey in February 1948, he was instructed to maintain Soviet demands and to be reserved in his relations with the Turks, but not to undertake any positive actions. ${ }^{90}$ The active Great Power in relation to Turkey after 1946 was not the USSR; it was the United States. After the Truman Doctrine speech in March 1947, American military aid poured into Turkey. By 1952 the country was in NATO, and it was the Soviets who were feeling the military pressure in the Black Sea and the Eastern Mediterranean, not the Turks. ${ }^{91}$ After Stalin's death the Soviet demands for territorial concessions and control of the Straits were quietly dropped.

According to Western Cold War lore, Stalin backed away from confrontation with Turkey because of strong British and American support for the Turks' stance on the Straits issue. It is true that in the absence of such support Stalin might have been inclined to press his demands further, including using the direct threat of military action to force concessions from the Turks. But it may be that it was not so much Western power that deterred Stalin as the negative political consequences of the prolongation and intensification of the Straits crisis. In summer 1946 the Soviets were still locked in difficult negotiations with the Western powers about the peace treaties for Bulgaria, Finland, Hungary, Italy and Romania - agreements seen by Moscow as crucial for the consolidation of the Soviet and communist position in Eastern Europe. The Straits crisis coincided with the Paris Peace Conference of July-October 1946 a multilateral meeting to consider the drafts of peace treaties for the minor Axis states. The conference failed to reach final agreement, but when the CFM reconvened in New York in November Soviet tactics softened and the path was opened to the compromises that resulted in the signature of those peace treaties in February 1947. The next item on the CFM agenda - discussed at its Moscow meeting in March-April 1947 - was the negotiation of a German

88 Kuniholm, Origins of the Cold War, op. cit., 372-3.

89 See Hasanli, SSSR-Turtsiya, op. cit., 370-3; and N.V. Kochkin, 'SSSR, Angliya, SShA i

“Turetskii Krizis” 1945-1947gg.', Novaya i Noveishaya Istoriya 3 (2002).

90 Gasanly, 'The "Turkish Crisis"', op. cit., pt 2, 131-2.

91 See M.P. Leffler, 'Strategy, Diplomacy, and the Cold War: The United States, Turkey, and NATO, 1945-1952', The Journal of American History 71(4) (March 1985). 
peace treaty. Stalin was obsessed with the danger of a German revival and remained committed to the joint implementation with the West of the Potsdam Agreement on the denazification, demilitarization and democratization of Germany. Viewed in this broader context, control of the Black Sea Straits was desirable but not essential, and the pursuit of a more aggressive policy not worth the complications it might bring to negotiations with the West in the European theatre.

Soviet policies in relation to Greece, Iran, and Turkey illustrate the different dimensions and dynamics of Stalin's postwar foreign strategy. In the case of Greece, Soviet policy was determined by Stalin's preference that the Greek communists avoid civil war if they could and pursue a mainly constitutional strategy for political advance. This preference was in accord with the general parliamentary-cum-democratic strategy of European communism in the early postwar years and fitted well with Moscow's efforts to secure a sphere of influence agreement with Britain and the United States. In the case of Iran, economic motives drove Stalin's diplomacy but policy was complicated by Moscow's efforts to exploit the country's ethnic divisions and nationalist politics. The politics of ethnicity and nationalism also played a role in relation to Turkey, but Moscow's prime concern was Soviet security in the Black Sea.

Stalin failed to achieve his aims in Greece, Iran, and Turkey. But equally striking was his consistent failure to press Soviet demands - indicative, I have argued, of the region's secondary place in his policy priorities. Possible gains on the USSR's southern periphery were subordinate to the consolidation of the Soviet sphere of influence in Eastern Europe. At the same time, the frustration of Stalin's goals in Greece, Iran, and Turkey did play an important role in shaping the Soviet narrative of the postwar denouement of the Grand Alliance. In the early postwar years, Stalin and other Soviet leaders made numerous public and private statements claiming that the USSR's predominant role in winning the war was not sufficiently appreciated in the West; that London and Washington refused to respect and recognize Moscow's new global power and interests; and that the USSR was being denied the just rewards of victory. As Stalin complained to Bevin in December 1945: 'as he saw the situation, the United Kingdom had India and her possessions in the Indian Ocean in her sphere of interest: the United States had China and Japan, but the Soviet Union had nothing., 92

It is tempting to characterize such statements as bluster and rhetoric originating from the first flush of Soviet victory over nazi Germany, and as a measure of the Great Power mentality that gripped Stalin after the war. Certainly, this was how they were seen by Western politicians such as Bevin and Byrnes, a perception that contributed to the view that the way to deal with the Soviets was a firm rebuff to bring them to their senses. Missing from this type of

92 DBPO, document 340, 868. 
response was any sense of the profound transformation of Soviet communist identity that had taken place during the war. ${ }^{93}$

From the very beginning, the war against Germany was waged as a patriotic struggle in defence of a multinational Soviet state that stood for the protection of all its peoples from murderous foreign invaders. This concept of the war built on a 1930s shift in communist politics toward a 'National Bolshevik' position that centred on a notion of the Soviet regime as the culmination of a thousand-year, popular patriotic struggle to maintain Russia's independence in the face of foreign threats. By the end of the war Soviet communism had redefined itself as being as much a patriotic political movement as a revolutionary and socialist one. This did not mean the communist party abandoned Marxist ideology or reneged on its commitments to international revolutionary goals. But the identity shift did mean that a much stronger sense of patriotic commitment and priorities came into play, not least in the sphere of foreign policy. In the context of this identity shift the frustration of Moscow's postwar ambitions in the Near East assumed greater importance than the intrinsic issues might otherwise have merited.

The identification of the 'patriotic factor' as an important, albeit intangible, influence on postwar Soviet foreign policy is not a new idea. During the Cold War one of the perennial debates about Moscow's foreign policy was the extent to which Soviet 'imperialism' was a form of Russian imperialism. ${ }^{94}$ Many scholars have noted the frequency with which Stalin and Molotov alluded in the early postwar period to the continuities between Tsarist and Soviet aims and policies. However, previous commentaries have not emphasized enough the specificity of Soviet communism's postwar patriot identity, as interpreted by Stalin. As Eric van Ree argued,

Stalin did not model his foreign policy on that of the Tsars. It was the other way around; he measured tsarist foreign policy in its various stages against the standard of his own goal of a strong multinational Soviet Union, unifying a number of nations under Russian leadership, but with a limit set on further expansion of Soviet borders arising from the same national principle. $^{95}$

Stalin was determined to succeed where the Tsars had failed and to secure stable ethnic borders for the Soviet Union, as well as a strong geopolitical

93 On the transformation of the Soviet communist identity, especially during the war, see D. Brandenberger, National Bolshevism: Stalinist Mass Culture and the Formation of Modern Russian National Identity, 1931-1956 (Cambridge, MA, and London 2002); van Ree, Political Thought of Joseph Stalin, op. cit.; G. Hosking, 'The Second World War and Russian National Consciousness', Past and Present 175 (2002); A. Vdovin, 'Natsional'nyi Vopros u natsional'naya politika v SSSR v gody Velikoi Otechestvennoi Voiny: mifi i realii', Vestnik Moskovskogo Universiteta: Seriya 8: Istoriya 5 (2003); T.K. Blauvelt, 'Military Mobilisation and National Identity in the Soviet Union', War and Society 21(1) (May 2003); and G. Roberts, Stalin's Wars: From World War to Cold War (London 2006).

94 See, for example, the essays in I.J. Lederer (ed.), Russian Foreign Policy: Essays in Historical Perspective (New Haven, CT, and London 1962).

95 Van Ree, Political Thought of Joseph Stalin, op. cit., 241. 
position in the Near East. As this article has shown, Stalin's patriotism was pragmatic and sensitive to the realities of power, but the frustration of his goals along the southern periphery of his postwar empire, seen as central to the Soviet state's new patriotic identity, was an important if not central cause of Moscow's contribution to the outbreak of the Cold War.

\section{Geoffrey Roberts}

is the professorial Head of the School of History at University College Cork, Ireland. His publications include: The Unholy Alliance: Stalin's Pact with Hitler (1989); The Soviet Union and the

Origins of the Second World War (1995); The Soviet in World Politics, 1945-1991 (1998); Victory at Stalingrad: The Battle that Changed History (2002); and Stalin's Wars: From World War to Cold War, 1939-1953 (2006). 